\title{
ŪMINIO IR LE்TINIO SKAUSMO PASIREIŠKIMAS INTERVENCIJOS VIETOJE PO PERKUTANINĖS KORONARINĖS INTERVENCIJOS
}

\author{
Liuda Brogienė ${ }^{1}$, Agnẻ Klimaitė², Arnas Lukošiūnas², Martynas Paliokas², Andrius Macas ${ }^{1}$ \\ ${ }^{1}$ Lietuvos sveikatos mokslu universiteto Anesteziologijos klinika, \\ ${ }^{2}$ Lietuvos sveikatos mokslu universitetas
}

Raktažodžiai: ūminis skausmas, ūminis užsitęsęs skausmas, lètinis skausmas, lokalus skausmas, poprocedūrinis skausminis sindromas, perkutaninè koronarinè intervencija.

\begin{abstract}
Santrauka
Ūminis bei lètinis skausmas punkcijos vietoje po perkutaninès koronarinès intervencijos (PKI) yra nepakankamai îvertinta būklé, kuriai skiriama per mažai dėmesio. Šis tyrimas atskleidžia skausmo pasireiškimo dažnị punkcijos vietoje po PKI bei jo atsiradimą sąlygojančius rizikos veiksnius.

Tyrimo tikslas. Ūminio ir lètinio skausmo punkcijos vietoje po PKI pasireiškimo dažnio nustatymas bei jị sąlygojančių pacientų rizikos veiksnių identifikavimas.

Tyrimo medžiaga ir metodai. Duomenys tyrimui rinkti Lietuvos sveikatos mokslų universiteto Kauno klinikų (LSMUL KK) Kardiologijos klinikoje 2015 metu kovo-liepos mènesiais. Atsitiktiniu būdu atrinkti pacientai, kurie buvo stacionarizuoti planine tvarka PKI atlikti. Pacientai buvo apklausti po procedūros praejus $2,4,12,24,48$ valandoms pagal autorių sudarytą anketą. Buvo vertinamas skausmo atsiradimo ir išnykimo laikas, intensyvumas, pobūdis, taip pat ieškota galimų skausmo atsiradimą predisponuojančių rizikos veiksnių. Skausmo intensyvumui vertinti naudota žodinė aprašomoji skalè. Pacientams išvykus iš ligoninès su jais buvo kontaktuojama telefonu praejjus 1 savaitei, 1 bei 3 mènesiams po procedūros. Bioetikos leidimas informacijai apie pacientus rinkti gautas (Nr. BEC-MF-328). Statistinè duomenų analizè atlikta naudojant programą SPSS $23.0(\mathrm{p}<0,05)$.

Rezultatai ir išvados. Tyrimo laikotarpiu LSMUL KK iš viso buvo apklaustas 191 pacientas, iš kuriu 122 vyrai $(63,87 \%)$ ir 69 moterys $(36,13 \%)$. Üminis poprocedūrinis skausmas (iki 48 val.) po PKI pasi-
\end{abstract}

reiškė daugiau nei pusei pacientų $(53,4 \%)$. Daugumoje atveju jis buvo vidutinio stiprumo bei "bukas" $(32,23 \%)$, "dilgčiojantis" $(28,10 \%)$ ir "veržiantis" $(31,82 \%)$. Veiksniai, turintys įtakos ūminiam poprocedūriniam skausmui atsirasti: arterinè hipertenzija, moteriškoji lytis, baimès jausmas prieš PKI, hematoma, arterinis kraujavimas iš intervencijos vietos, skausmo jutimas procedūros metu. Namuose toliau buvo sekti 117 pacientų, iš kurių 18,80\% skundèsi ūminiu užsitęsusiu skausmu (po 48val. - iki 3 mèn.). Veiksniai, turintys įtakos ūminiam užsitęsusiam skausmui atsirasti: rūkymas, punkcijos vietos pakeitimas procedūros metu, hematoma, skausmo jutimas procedūros metu. $4,27 \%$ pacientų pasireiškè lètinis skausmas (po 3 mèn.) po PKI. Daugumoje atveju jis buvo stiprus (80\%) bei "buko" $(60 \%)$ ar "dilgčiojančio" (40\%) pobūdžio. Veiksniai, turintys itakos lètiniam skausmui atsirasti: hematoma punkcijos vietoje, punkcijos vietos pakeitimas procedūros metu, sumažèjęs diastolinis kraujo spaudimas, intervencijos trukmè $>30 \mathrm{~min}$.

\section{Ivadas}

Perkutaninè koronarinè intervencija yra dažniausiai taikomas metodas gydant širdies vainikinių arterijų patologijos sukeltas ligas dèl šios procedūros atlikimo paprastumo, greito gydymo efekto bei ankstyvos pacientų mobilizacijos po jos [1]. Pirmą kartą ši procedūra buvo atlikta 1929m. ir nuo to laiko nuolat tobulèjo bei igavo svarbią diagnostinę bei gydomają reikšmę medicinoje [2]. Priklausomai nuo kateterio įleidimo vietos išskiriami du dažniausiai naudojami PKI atlikimo būdai: per stipininę arteriją (transradialinis; TR) arba per šlaunies arteriją (transfemoralinis; TF). Ilgą laiką TF buvo pagrindinis ir praktiškai nepakeičiamas metodas iki 1989 m., kuomet Campeau atliko pirmają TR širdies kateterizaciją. Kiek vèliau Kiemeneij ir Laarman, patobulinę šią procedūrą, atliko ir angioplastiką kartu su stentavimu [3]. Šiuo metu pirmo pasirinkimo interverci- 
jos vieta yra stipininè arterija dèl mažesnio su punkcijos vieta susijusių komplikacijų dažnio lyginant su šlaunies arterija $[4,5]$. Nepaisant PKI atlikimo saugumo bei naudos pacientui gali sukelti ir neigiamų padarinių. Dabartiniuose tyrimuose dažniausiai minimos šios, su punkcijos vieta susijusios, komplikacijos: ūmi arterijos trombozé, okliuzija, spazmas, sunkiai kontroliuojamas kraujavimas (galintis sąlygoti hematomas intervencijos vietoje, jų išplitimą, taip pat ir kompartmento sindromą), pseudoaneurizma, arterioveninè fistule, nervo pažeidimas bei infekcija, kurių pasireiškimo dažnis, atsižvelgiant ị literatūros šaltinius, varijuoja [6]. Kraujagyslinès komplikacijos, t.y. kraujavimas iš punkcijos vietos bei arterijos spazmas yra vienos iš dažniausių ir labiausiai aprašomų moksliniuose straipsniuose [14]. Apie kitas, rečiau pasitaikančias, būkles po procedūros informacijos kol kas yra mažiau. Viena iš ju - skausminis sindromas punkcijos vietoje po PKI, kuris gali būti sąlygotas nervo pažeidimo intervencijos metu, nervo suspaudimo tvarsčiu ar dèl susiformavusios hematomos po kraujagyslès pažeidimo [7, 8]. Ūmus ir lètinis skausmas po procedūros yra retos, tačiau labai trikdančios paciento kasdieni gyvenimą bei ribojančios jo veiksnumą būklès [13] Jų pasireiškimo dažnis mažesnis nei $0,1 \%[6,9]$. Tačiau pastaruoju metu pristatoma vis daugiau klinikinių atvejų $[10,11]$, aprašančių būtent po PKI atsiradusị ūminị skausmą punkcijos vietoje, kuris negydomas gali pereiti ị lètini skausmą. Šiame straipsnyje aprašomas tyrimas, kuriame vertintas ūminio bei lètinio skausmo atsiradimas intervencijos vietoje po PKI.

Mūsų tyrimo tikslas buvo nustatyti ūminio ir lètinio skausmo intervencijos vietoje po PKI pasireiškimo dažni bei jị sąlygojančius pacientų rizikos veiksnius.

\section{Tyrimo medžiaga ir metodai}

Tyrimo populiacija: 2015 metais, nuo kovo iki liepos mèn. LSMUL KK Kardiologijos klinikoje buvo apklausiami ir perspektyviai sekami pacientai, kuriems atlikta PKI (taikant TR arba TF intervencijos metodus). Dalyviai buvo atrinkti atsitiktiniu būdu ị tyrimą ịtraukiant tik tuos, kuriems PKI atlikta planine tvarka. Visi pacientai buvo deramai informuoti ir davė rašytinị sutikimą dalyvauti mūsų studijoje (bioetikos leidimas, Nr. BEC-MF-328). Dalyvavusieji buvo apklausiami pagal autoriu sudarytą anketą. Apklausos metu buvo registruojami šie galimi rizikos veiksniai: pacientų amžius, lytis, kūno masės indeksas $>25$ (KMI), arterinis kraujo spaudimas, baimè prieš procedūrą, pirminè arterinè hipertenzija, dislipidemija, cukrinis diabetas, depresija, reumatoidinis artritas, riešo tunelinis sindromas, rūkymas, stentavimas PKI metu, intervencijos trukmè, punkcijos vietos lokalizacija, jos keitimas, užspau- dimo trukmè, arterinis kraujavimas iš intervencijos vietos, jos patinimas, susiformavusios hematoma, pseudoaneurizma, arterjos trombozè, AV fistule, neuropatija, punkcijos vietos infekcija, skausmas prieš ar per intervenciją.

Tyrimo metu LSMUL KK Kardiologijos klinikos pagrindine intervencijos vieta buvo dešiniosios rankos stipininè arterija. Taikant TR metodą, prieš procedūrą palpacijos būdu randama stipininès arterijos vieta, nustatomas pulso joje stiprumas bei kraujagyslès eiga. PKI atliekama po oda suleidžiant vietinio anestetinio preparato $(0,5-1 \mathrm{ml}$ $1 \%$ lidokaino tirpalo), tuo siekiant sumažinti skausmą intervencijos vietoje bei galimą arterijos spazmą, galintị sąlygoti nepavykusi procedūros atlikimą $[4,12]$. Taikant ši metodą hemostazè buvo atliekama uždedant spaudžiamaji tvarstị intervencijos vietoje ir laikant ji užveržtą vidutiniškai $18,6 \pm 5,5$ val. po procedūros.

Tyrimo metu antrojo pasirinkimo PKI intervencijos vieta buvo dešiniosios kojos (bendroji) šlaunies arterija. Ji randama palpacijos būdu ties kirkšnies raiščio viduriu, kuriam identifikuoti kaip anatominiai orientyrai naudojami klubakaulio skiautere bei gaktikaulis. Siekiant sumažinti skausmą bei galimą arterijos spazmą prieš punkciją po oda suleidžiama vietinio anestetinio preparato. Hemostazė taikyta uždedant spaudžiamajị smèlio maišą ant intervencijos vietos, kuris buvo laikytas vidutiniškai $8,8 \pm 5,2$ val. Pirmas 6val. po procedūros pacientas privalo gulèti ant nugaros bei negali judinti dešiniosios kojos, siekiant išvengti poprocedūrinio kraujavimo ir hematomos susidarymo intervencijos vietoje.

Atliekant ši tyrimą pacientai buvo sekami ir informacija apie juos rinkta tiek stacionare, tiek ir išvykus iš jo. Pacientų sekimas stacionare: pirmąsias 48val. po PKI visi tyrime dalyvavusieji pacientai sekti ligoninèje. Apklausa buvo kartojama šiais laiko tarpais: po 2 val., po 12 val., po 24 val. ir po 48 val. po intervencijos, kiekvieną kartą vertinant skausmą bei kitas pasireiškusias komplikacijas, kaip kraujavimas iš punkcijos vietos ir hematoma. Pacientų sekimas jiems išvykus iš ligoninès: visi pacientai, kurie sutiko toliau dalyvauti mūsu tyrime ir pateikè savo kontaktinius duomenis, buvo apklausiami jiems išvykus iš stacionaro, išskyrus tuos pacientus, kuriems po PKI buvo rekomenduotas operacinis gydymas - aortos-vainikinių arterijų jungčių operacija. Su kiekvienu iš jų buvo susisiekta telefonu praejjus 1 savaitei, 1 ir 3 ménesiams po atliktos PKI. Kiekvieną kartą pokalbio metu, kaip ir stacionare, buvo vertintas skausmas punkcijos vietoje bei kitos pasireiškusios komplikacijos.

Skausmo vertinimas: kiekvieną kartą, tiek pacientui būnant stacionare, tiek susisiekus su juo telefonu, buvo nuosekliai klausiama apie skausmo atsiradimą punkcijos vietoje po PKI. Kiekvienam pacientui, kuris skundèsi skausmu, 

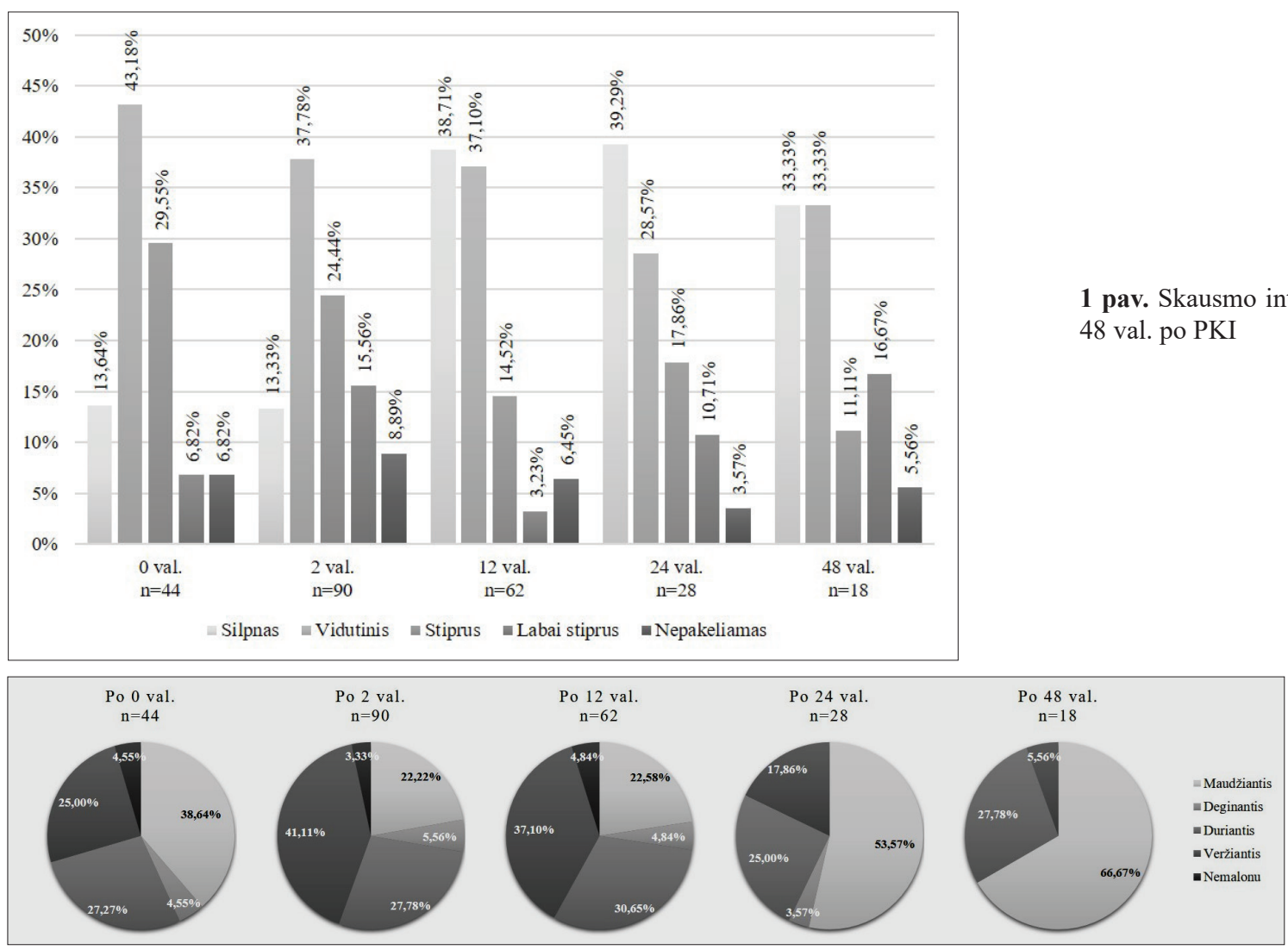

1 pav. Skausmo intensyvumas iki 48 val. po PKI

2 pav.

Skausmo pobūdis iki 48 val. po PKI

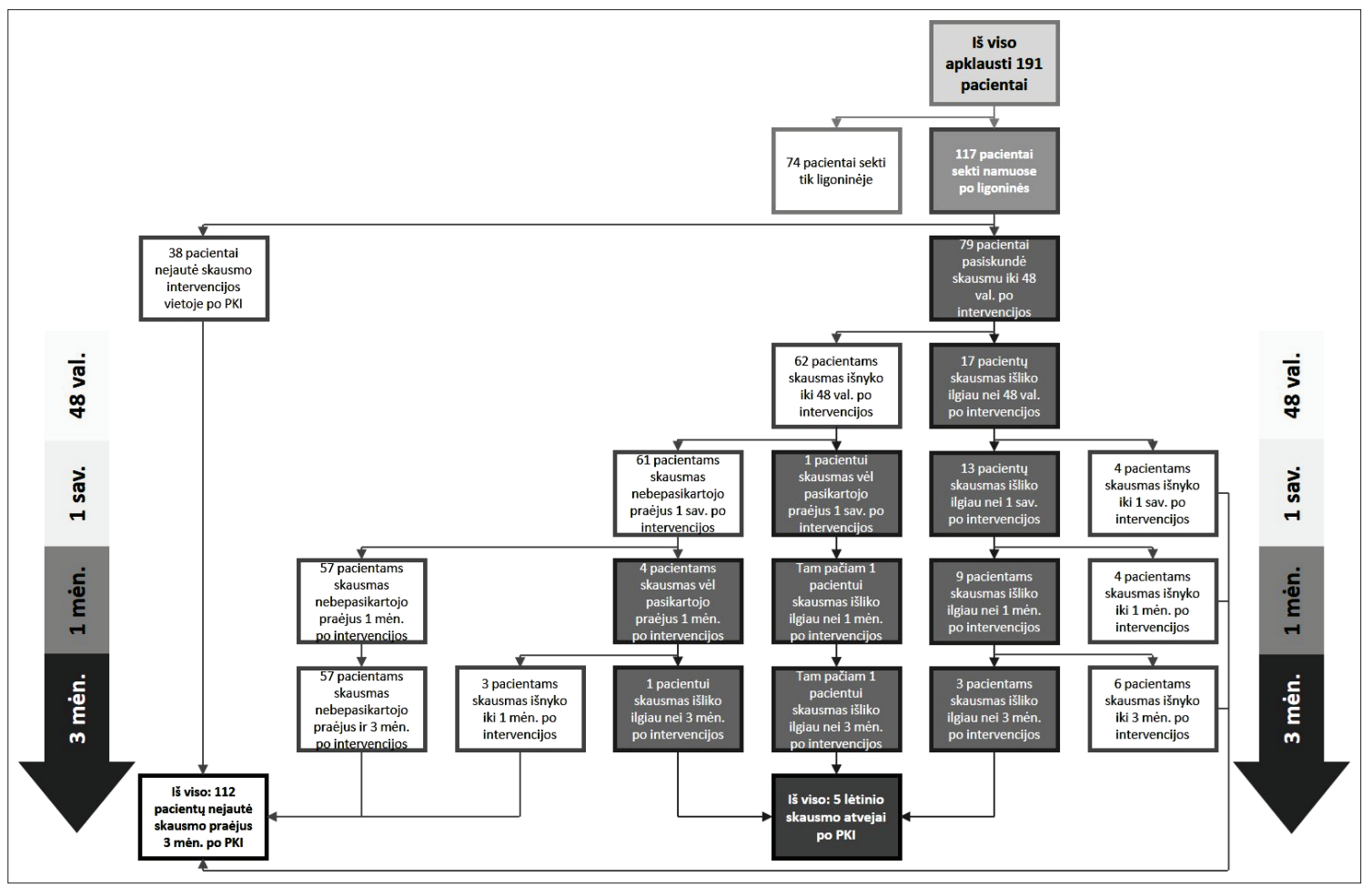

3 pav.

Skausmo punkcijos vietoje po PKI pokyčiai sekamojoje grupejje 


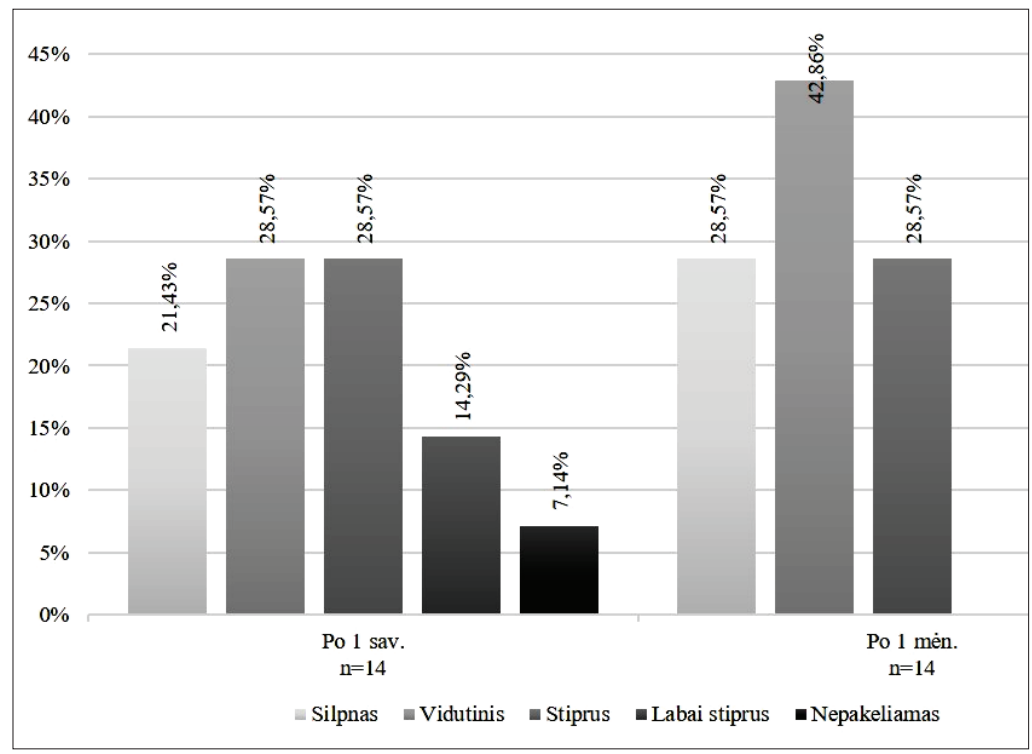

4 pav. Skausmo intensyvumas po PKI praejus $>48$ val., bet $<3$ mèn.

buvo vertinami 7 skausmo klausimai (skausmo vieta, jo plitimas, pobūdis, intensyvumas, atsiradimo aplinkybės, skausmą mažinantys/didinantys veiksniai, lydintys požymiai). Skausmo intensyvumas buvo vertinamas naudojant žodinę aprašomają skalę: jokio skausmo (0balų), silpnas (1b.), vidutinis (2b.), stiprus (3b.), labai stiprus (4b.), nepakeliamas skausmas (5b.). Skausmo pobūdis buvo vertinamas leidus pacientui pasirinkti pačiam iš šių grupių: bukas, deginantis, dilgčiojantis, veržiantis ar nemalonus.

Vertinant rezultatus apie atsiradusį skausmą punkcijos vietoje po PKI jis buvo suskirstytas ị tris grupes: ūminis poprocedūrinis skausmas (pasireiškęs ir trukęs iki 48val. po procedūros), ūminis užsitęsęs skausmas (pasireiškęs ir trukęs mažiau nei 3 mèn.) ir lètinis skausmas (pasireiškęs ir trukęs 3 mèn. ar ilgiau).

Statistinè informacija analizuota naudojant duomenų paketą SPSS 23.0. Taikyta: neparametrinis Mann-Whitney, $\chi^{2}$ - požymių nepriklausomumo kriterijus. Skirtumai bei priklausomybès tarp požymių buvo laikyti statistiškai reikšmingais, kai $\mathrm{p}<0,05$.

\section{Rezultatai}

Tyrime dalyvavo 191 pacientas, iš kuriu 122 vyrai $(63,87 \%)$ ir 69 moterys (36,13\%). Vidutinis dalyvavusiujų amžius buvo $67,3 \pm 10,49$ metai. 150 pacientų $(78,53 \%)$ kateterizuoti per stipininę arteriją, 41 pacientas $(21,47 \%)$ - per šlaunies arteriją. Statistiškai reikšmingos priklausomybès tarp intervencijos vietos ir skausmo po jos pasireiškimo dažnio nestebėta. 102 pacientai $(53,4 \%)$ jautė ūmų poprocedūrini skausmą bent kartą per pirmas 48 val. po PKI. Skausmo pasireiškimo dažnis bei skausmo intensyvumas svyravo per pirmas 48 val. po intervencijos (1 pav.).

Pacientai skausmo pobūdị ịvertino ịvairiai (2 pav.). Apibendrinant dažniausiai skausmas apibūdintas kaip "maudžiantis" (32,23\%), "duriantis" $(28,10 \%)$ ir "veržiantis" $(31,82 \%)$.
Rizikos veiksniai, turintys statistiškai reikšmingą ịtaką ūminiam poprocedūriniam skausmui po PKI atsirasti yra arterinè hipertenzija $(\mathrm{p}=0,015)$, moteriškoji lytis $(\mathrm{p}=0,014)$, baimès jausmas prieš PKI $(\mathrm{p}=0,005)$, hematoma $(\mathrm{p}=0,000248)$, arterinis kraujavimas iš intervencijos vietos $(\mathrm{p}=0,005)$, skausmo jutimas procedūros metu ( $\mathrm{p}=0,000003)$ (1 lent.). Kiti rizikos faktoriai šiam skausmui išsivystyti itakos neturèjo.

Iš 191117 dalyvių buvo įtraukti ì sekamujų grupę. Pastarojoje buvo 74 vyrai $(63,25 \%)$ ir 43 moterys $(36,75 \%)$. Pacientu vidutinis amžius $-67,3 \pm 10,49$ metai. 92 apklaustieji $(78,63 \%)$ buvo kateterizuoti per stipininę arteriją, 25 (21,37\%) - per šlaunies arteriją. Statistiškai reikšmingos priklausomybès tarp intervencijos vietos ir skausmo po jos pasireiškimo dažnio nestebèta. Laikotarpiu nuo 48 val. iki daugiau nei 3 mèn. po PKI skausmo pasireiškimo atvejų skaičius neišliko pastovus (3 pav.). Pacientai, kurie nejaute skausmo per pirmas 48val. po procedūros, skausmu nesiskunde ir laikotarpiu nuo 48 val. iki 3 mèn., t.y. jiems nepasireiškè nei ūminis užsitęsęs, nei lètinis skausmas. Tuo tarpu 79 pacientai skundèsi ūmiu poprocedūriniu skausmu. Iš jų 17-ai skausmas truko ilgiau nei 48 val., ir 5-iems - ilgiau nei 3 mèn.

Ivertinus skausmo pasireiškimo dažnio bei skausmo intensyvumo pokyčius laikotarpiu nuo 48val. iki mažiau nei 3 mėn. (4 pav.) po intervencijos matoma, jog praejjus 1 sav. dominavo vidutinio stiprumo ir stiprus, o praejjus 1 mèn. po PKI - vidutinio stiprumo skausmas.

Rizikos veiksniai, turintys statistiškai reikšmingą itaką ūminiam užsitęsusiam skausmui po PKI atsirasti yra rūkymas $(\mathrm{p}=0,016)$, punkcijos vietos pakeitimas intervencijos metu $(\mathrm{p}=0,007)$, hematoma $(p=0,0003)$, skausmo jutimas intervencijos metu $(p=0,002)$ (1 lentelè). Kiti rizikos faktoriai šiam skausmui išsivystyti įtakos neturejo.

5 pacientams $(4,27 \%)$ iš sekamujų grupès skausmas išliko ilgiau nei 3 mèn. (lètinis skausmas) po PKI: $20 \%(n=1)$ jų jaute vidutinio stiprumo, $80 \%(n=4)$ - stiprų skausmą. 
1 lentelè. Pagrindiniai skausmo, punkcijos vietoje po PKI, parametrai

\begin{tabular}{|c|c|c|c|c|c|c|c|c|c|}
\hline & \multicolumn{3}{|c|}{ Ūminis skausmas ( $\leq 48$ val.) } & \multicolumn{3}{|c|}{$\begin{array}{c}\text { Užsitęsęs ūminis skausmas ( } \geq 48 \text { val. }-<3 \\
\text { mèn.) }\end{array}$} & \multicolumn{3}{|c|}{ Lètinis skausmas ( $\geq 3$ mèn.) } \\
\hline & $\begin{array}{c}\text { Skausmo } \\
\text { nejaute } \\
(\mathrm{n}=89)\end{array}$ & $\begin{array}{c}\text { Skausmą } \\
\text { jautė } \\
(\mathrm{n}=102)\end{array}$ & $\mathrm{p}$ & $\begin{array}{c}\text { Skausmo } \\
\text { nejaute } \\
(\mathrm{n}=95)\end{array}$ & $\begin{array}{c}\text { Skausmą } \\
\text { jautė } \\
(n=22)\end{array}$ & $\mathrm{p}$ & $\begin{array}{c}\text { Skausmo } \\
\text { nejaute } \\
(n=112)\end{array}$ & $\begin{array}{l}\text { Skausmą } \\
\text { jautė }(n=5)\end{array}$ & $\mathrm{p}$ \\
\hline Amžius (metai) & $67,1 \pm 11,5$ & $67,4 \pm 9,6$ & 0,854 & $65,9 \pm 9,8$ & $64,4 \pm 9,3$ & 0,603 & $65,3 \pm 9,7$ & $73,2 \pm 4,0$ & 0,062 \\
\hline Moterys & $24(27,0 \%)$ & $45(44,1 \%)$ & 0,014 & $34(35,8 \%)$ & $9(40,9 \%)$ & 0,654 & $40(35,7 \%)$ & $3(60,0 \%)$ & 0,355 \\
\hline $\mathrm{KMI}\left(\mathrm{kg} / \mathrm{m}^{2}\right)$ & $28,5 \pm 4,5$ & $28,9 \pm 4,5$ & 0,576 & $28,9 \pm 4,3$ & $28,4 \pm 3,8$ & 0,582 & $28,8 \pm 4,3$ & $28,3 \pm 1,1$ & 0,808 \\
\hline MIC (metai) & $10,1 \pm 10,3$ & $13,1 \pm 11,6$ & 0,057 & $11,6 \pm 9,7$ & $12,4 \pm 14,5$ & 0,564 & $12,0 \pm 10,8$ & $5,8 \pm 5,8$ & 0,168 \\
\hline SAKS (mmHg) & $143,3 \pm 22,0$ & $144,9 \pm 20,3$ & 0,344 & $144,1 \pm 21,3$ & $137,3 \pm 20,5$ & 0,193 & $143,5 \pm 20,9$ & $128,0 \pm 25,9$ & 0,197 \\
\hline DAKS (mmHg) & $85,17 \pm 10,0$ & $84,1 \pm 11,8$ & 0,447 & $85,1 \pm 10,8$ & $85,5 \pm 15,7$ & 0,883 & $85,6 \pm 11,6$ & $74,0 \pm 11,4$ & 0,034 \\
\hline Skirtumas (mmHg) & $58,1 \pm 17,3$ & $60,8 \pm 17,0$ & 0,162 & $59,1 \pm 16,4$ & $51,8 \pm 12,2$ & 0,086 & $57,9 \pm 15,9$ & $54,0 \pm 18,2$ & 0,694 \\
\hline PKI + stentavimas & $42(47,2 \%)$ & $58(56,9 \%)$ & 0,182 & $49(51,6 \%)$ & $16(72,7 \%)$ & 0,072 & $61(54,5 \%)$ & $4(80,0 \%)$ & 0,380 \\
\hline $\begin{array}{l}\text { Intervencijos trukmé } \\
\text { (min.) }\end{array}$ & $40,3 \pm 33,3$ & $38,5 \pm 29,7$ & 0,884 & $38,8 \pm 31,7$ & $47,1 \pm 37,3$ & 0,384 & $39,9 \pm 33,2$ & $51,0 \pm 22,5$ & 0,064 \\
\hline Baimė prieš & $7(7,9 \%)$ & $23(22,5 \%)$ & 0,005 & $18(18,9 \%)$ & $1(4,5 \%)$ & 0,099 & $19(17,0 \%)$ & $0(0,0 \%)$ & 0,590 \\
\hline Rūkymas & $25(28,1 \%)$ & $39(38,2 \%)$ & 0,138 & $30(31,6 \%)$ & $13(59,1 \%)$ & 0,016 & $42(37,5 \%)$ & $1(20,0 \%)$ & 0,651 \\
\hline $\begin{array}{l}\text { Riešo tunelinis } \\
\text { sindromas }\end{array}$ & $2(2,2 \%)$ & $3(2,9 \%)$ & 1,000 & $4(4,2 \%)$ & $0(0,0 \%)$ & 1,000 & $4(3,6 \%)$ & $0(0,0 \%)$ & 1,000 \\
\hline $\mathrm{CD}$ & $18(20,2 \%)$ & $13(12,7 \%)$ & 0,162 & $14(14,7 \%)$ & $3(13,6 \%)$ & 1,000 & $16(14,3 \%)$ & $1(20,0 \%)$ & 0,551 \\
\hline PAH & $63(70,8 \%)$ & $87(85,3 \%)$ & 0,015 & $72(75,8 \%)$ & $18(81,8 \%)$ & 0,779 & $86(76,8 \%)$ & $4(80,0 \%)$ & 1,000 \\
\hline Dislipidemija & $55(61,8 \%)$ & $58(56,9 \%)$ & 0,489 & $61(64,2 \%)$ & $11(50,0 \%)$ & 0,217 & $69(61,6 \%)$ & $3(60,0 \%)$ & 1,000 \\
\hline RA & $3(3,4 \%)$ & $1(1,0 \%)$ & 0,340 & $2(2,1 \%)$ & $0(0,0 \%)$ & 1,000 & $2(1,8 \%)$ & $0(0,0 \%)$ & 1,000 \\
\hline Depresija & $2(2,2 \%)$ & $1(1,0 \%)$ & 0,599 & $1(1,1 \%)$ & $0(0,0 \%)$ & 1,000 & $1(0,9 \%)$ & $0(0,0 \%)$ & 1,000 \\
\hline $\begin{array}{l}\text { Intervencija atlikta } \\
\text { pirmą kartą }\end{array}$ & $47(52,8 \%)$ & $57(55,9 \%)$ & 0,671 & $50(52,6 \%)$ & $10(45,5 \%)$ & 0,544 & $58(51,8 \%)$ & $2(40,0 \%)$ & 0,674 \\
\hline $\begin{array}{l}\text { Punkcijos vieta } \\
\text { a.radialis }\end{array}$ & $66(74,2 \%)$ & $84(82,4 \%)$ & 0,169 & $76(80,0 \%)$ & $16(72,7 \%)$ & 0,453 & $89(79,5 \%)$ & $3(60,0 \%)$ & 0,290 \\
\hline $\begin{array}{l}\text { Punkcijos vietos } \\
\text { keitimas }\end{array}$ & $3(3,4 \%)$ & $7(6,9 \%)$ & 0,280 & $3(3,2 \%)$ & $4(18,2 \%)$ & 0,007 & $5(4,5 \%)$ & $2(40,0 \%)$ & 0,028 \\
\hline Patinimas & $35(39,3 \%)$ & $73(71,6 \%)$ & 0,000007 & $56(58,9 \%)$ & $14(63,6 \%)$ & 0,686 & $66(58,9 \%)$ & $4(80,0 \%)$ & 0,647 \\
\hline $\begin{array}{l}\text { Arterinis } \\
\text { kraujavimas }\end{array}$ & $3(3,4 \%)$ & $16(15,7 \%)$ & 0,005 & $8(8,4 \%)$ & $4(18,2 \%)$ & 0,174 & $11(9,8 \%)$ & $1(20,0 \%)$ & 0,424 \\
\hline Hematoma & $15(16,9 \%)$ & $42(41,2 \%)$ & 0,000248 & $26(27,4 \%)$ & $15(68,2 \%)$ & 0,0003 & $37(33,0 \%)$ & $5(100,0 \%)$ & 0,05 \\
\hline Pseudoaneurizma & $0(0,0 \%)$ & $0(0,0 \%)$ & - & $0(0,0 \%)$ & $0(0,0 \%)$ & - & $0(0,0 \%)$ & $0(0,0 \%)$ & - \\
\hline Arterijos trombozè & $0(0,0 \%)$ & $0(0,0 \%)$ & - & $0(0,0 \%)$ & $0(0,0 \%)$ & - & $0(0,0 \%)$ & $0(0,0 \%)$ & - \\
\hline AV fistulè & $0(0,0 \%)$ & $0(0,0 \%)$ & - & $0(0,0 \%)$ & $0(0,0 \%)$ & - & $0(0,0 \%)$ & $0(0,0 \%)$ & - \\
\hline Neuropatija & $0(0,0 \%)$ & $0(0,0 \%)$ & - & $0(0,0 \%)$ & $0(0,0 \%)$ & - & $0(0,0 \%)$ & $0(0,0 \%)$ & - \\
\hline Infekcija & $0(0,0 \%)$ & $0(0,0 \%)$ & - & $0(0,0 \%)$ & $0(0,0 \%)$ & - & $0(0,0 \%)$ & $0(0,0 \%)$ & - \\
\hline $\begin{array}{l}\text { Skausmas prieš } \\
\text { intervenciją }\end{array}$ & $1(1,1 \%)$ & $4(3,9 \%)$ & 0,374 & $2(2,1 \%)$ & $0(0,0 \%)$ & 1,000 & $2(1,8 \%)$ & $0(0,0 \%)$ & 1,000 \\
\hline $\begin{array}{l}\text { Skausmas per } \\
\text { intervenciją }\end{array}$ & $8(9,0 \%)$ & $39(38,2 \%)$ & 0,000003 & $21(22,1 \%)$ & $12(54,5 \%)$ & 0,002 & $30(26,8 \%)$ & $3(60,0 \%)$ & 0,135 \\
\hline
\end{tabular}

Duomenys pateikti kaip vidurkis \pm standartinis nuokrypis arba n (\%). KMI: kūno masès indeksas; MIC: morbus ishaemicus cordis; SAKS: sistolinis arterinis kraujo spaudimas; DAKS: diastolinis arterinis kraujo spaudimas; Skirtumas: SAKS ir DAKS skirtumas; PKI: perkutanine koronarine intervencija; CD: cukrinis diabetas; PAH: pirmine arterine hipertenzija; $R A$ : reumatoidinis artritas; $A V$ : arteriovenine

Pacientai lètini skausmą charakterizavo kaip "buko" (60\%; n=3) ar "dilgčiojančio" $(40 \% ; n=2)$ pobūdžio.

Rizikos veiksniai, turintys statistiškai reikšmingą ịtaką lètiniam skausmui po PKI atsirasti, yra sumažèjęs diastolinis kraujo spaudimas $(\mathrm{p}=0,034)$, punkcijos vietos pakeitimas procedūros metu $(\mathrm{p}=0,028)$, hematoma $(\mathrm{p}=0,05) \quad(1$ lentelè) ir intervencijos trukmè $>30 \mathrm{~min} .(\mathrm{p}=0,013)$. Kiti rizikos faktoriai lètiniam skausmui išsivystyti ịtakos neturèjo.

\section{Diskusija}

Šiuo metu mokslinejje literatūroje nepakanka informacijos apie ūminị bei lètinị skausmą po PKI dèl su šia problema susijusių darbų stokos. Ši priežastis paskatino at- likti tyrimą šia tema. PKI dabartinèje medicinoje yra ypač vertinamas, plačiai naudojamas ir daug naudos teikiantis diagnostikos ir gydymo būdas. Tačiau remdamiesi mūsų tyrimo išvadomis matome, jog ši procedūra gali sukelti skausmini sindromą. Ūminio poprocedūrinio skausmo atvejai buvo fiksuoti daugiau nei pusei pacientų. Dar didesnè problema yra, jog net $4,27 \%$ tyrime dalyvavusiujų pacientų ūminis skausmas po PKI išliko ilgiau nei 3 mèn., t.y. perèjo ị lètinị skausmą.

Remdamiesi rezultatais matome, jog didžiausiai daliai žmonių skausmas pasireiškẻ per pirmąsias 48 val. po intervencijos. Pacientai, kurie nejaute skausmo per pirmas 48 val. po procedūros, skausmu nesiskundè ir laikotarpiu nuo 48 val. iki 3 mèn., t.y. jiems nepasireiškẻ nei ūminis užsi- 
tęsęs, nei lètinis skausmas. Tuo tarpu 79 pacientai skundėsi ūmiu poprocedūriniu skausmu ir iš jų 17-ai skausmas truko ilgiau nei 48 val., o 5-iems - ilgiau nei 3 mèn. Iš to galima daryti išvadą, jog siekiant išvengti létinio skausmo atsiradimo, būtinas nevèluojantis ir adekvatus ūminio skausmo malšinimas.

Reikia atkreipti dèmesí, jog šiame darbe neregistruotas analgetiku skyrimas pacientui bei intervencijos vietoje atsiradusios hematomos dydis.

\section{Išvados}

Ūminis poprocedūrinis skausmas po PKI pasireiškè daugiau nei pusei pacientų . Daugumoje atvejų jis buvo vidutinio stiprumo bei "bukas", "dilgčiojantis" ir "veržiantis". Veiksniai, turintys statistiškai reikšmingą itaką ūminiam poprocedūriniam skausmui po PKI atsirasti, yra arterinè hipertenzija, moteriškoji lytis, baimès jausmas prieš PKI, hematoma, arterinis kraujavimas iš intervencijos vietos, skausmo jutimas procedūros metu. Veiksniai, turintys statistiškai reikšmingą ịtaką ūminiam užsitęsusiam skausmui po PKI atsirasti, yra rūkymas, punkcijos vietos pakeitimas procedūros metu, hematoma, skausmo jutimas procedūros metu.

Lètinis skausmas po PKI pasireiškè 4,27\% pacientų. Daugumoje atvejų jis buvo stiprus bei "buko" ar "dilgčiojančio" pobūdžio. Rizikos veiksniai, turintys statistiškai reikšmingą ịtaką lètiniam skausmui po PKI atsirasti, yra sumažejęs diastolinis kraujo spaudimas, punkcijos vietos pakeitimas procedūros metu, hematoma, intervencijos tru$\mathrm{kme}>30 \mathrm{~min}$.

\section{Literatūra}

1. Cho EJ, Yang JH, Song YB. Type II complex regional pain syndrome of the hand resulting from repeated arterial punctures during transradial coronary intervention. Catheter Cardiovasc Interv 2013:82(4):E465-E468.

https://doi.org/10.1002/ccd.24853

2. Sachdeva S, Saha S. Transradial approach to cardiovascular interventions: an update. Int J Angiol. 2014;23(2):77-84.

https://doi.org/10.1055/s-0034-1372243

3. Elgharib NZ, Shah UH, Coppola JT. Transradial cardiac catheterization and percutaneous coronary intervention: a review. Coron Artery Dis 2009; 20(8):487-493.

https://doi.org/10.1097/MCA.0b013e32832f37fc

4. Bazemore E, Mann JT 3rd. Problems and complications of the transradial approach for coronary interventions: a review. J Invasive Cardiol 2005;17(3):156-159.

5. Shroff A, Siddiqui S, Burg A, Singla I. Identification and managment of complications of transradial procedures. Curr Cardiol Rep 2013; 15(4):350. https://doi.org/10.1007/s11886-013-0350-x

6. Kanei Y, Kwan T, Nakra NC. et al. Transradial cardiac catheterization: a review of access site complications. Catheter Cardiovasc Interv 2011; 78(6):840-846.

https://doi.org/10.1002/ccd.22978

7. Merriweather N, Sulzbach-Hoke LM. Managing risk of complications at femoral vascular access sites in percutaneous coronary intervention. Crit Care Nurse 2012;32(5):16-29. https://doi.org/10.4037/ccn2012123

8. Narouze SN, Zakari A, Vydyanathan A. Ultrasound-guided placement of a permanent percutaneous femoral nerve stimulator leads for the treatment of intractable femoral neuropathy. Pain Physician 2009;12(4):E305-E308.

9. Sanmartin M, Cuevas D, Goicolea J, et al. Vascular complications associated with radial artery access for cardiac catheterization. Rev Esp Cardiol 2004; 57(6):581-584.

10. Papadimos TJ, Hofmann JP. Radial artery thrombosis, palmar arch systolic blood velocities, and chronic regional pain syndrome 1 following transradial cardiac catheterization. Catheter Cardiovasc Interv 2002;57:537-540.

https://doi.org/10.1002/ccd.10367

11. Sasano N, Tsuda T, Sasno H. et al. A case of complex regional pain syndrome type II after transradial coronary intervention. J Anesth 2004;18(4):310-312.

https://doi.org/10.1007/s00540-004-0266-0

12. Bilodeau ML, Simon DI. Transradial Basics. Cardiac Interv today 2010;23(2):25-32.

13. Jang HJ, Kim JY, Han JD. et al. Numbness after transradial cardiac catheterization: the results from a nerve conduction study of the superficial radial nerve. Korean Circ J 2016;46(2):161168. https://doi.org/10.4070/kcj.2016.46.2.161

14. Nathan S, Rao SV. Radial versus femoral access for percutaneous coronary intervention: implications for vascular complications and bleeding. Curr Cardiol Rep 2012;14(4):502-509 https://doi.org/10.1007/s11886-012-0287-5

\section{PREVALENCE OF ACUTE AND CHRONIC PAIN AT INTERVENTION SITE AFTER PERCUTANEOUS CORONARY INTERVENTION}

\section{Brogienė, A. Klimaitè, A. Lukošiūnas, M. Paliokas,}

A. Macas

Key words: acute pain, chronic pain, local pain after percutaneous coronary intervention (PCI), local pain risk factors, local compications after PCI.

Background and Goal of study. Pain after percutaneous coronary intervention (PCI) is underestimated problem, which has a lack of attention. In this study we report the prevalence, pain intensity and predisposing factors of acute and chronic pain after PCI procedure.

Material and methods. The Data of randomly selected patients who underwent elective PCI using transradial or transfemoral approach in Hospital of Lithuanian University of Health Sciences 
Kaunas Clinics Cardiology department from March to July of 2015 was collected. Patients were questioned according to survey made by authors. Pain intensity was evaluated according to verbal analogue scales (no pain -NP, mild -mP, moderate - MP severe -SP, very severe -VSP and worst possible pain -WPP) 2, 12, 24 and 48 hours after PCI. Patients were interviewed after 1 week, 1 and 3 months after PCI when they were discharged. Pain manifestation and duration time was divided in three groups: acute postoperative pain (pain occured during first 48 hours after PCI), acute prolonged pain (patients felt pain more than 48 hours, but less than 3 months after PCI), chronic pain (pain lasted more than 3 months after PCI). We investigated factors that may have influence for development of pain such as: in- site hematoma, patient age, body mass index $>25$, gender, arterial hypertension, arterial bleeding from puncture site, diabetes mellitus, signs of the presence of cardiovascular disease time, dyslipidaemia, PCI duration, location of intervention, fear before procedure, smoking, depression, pain during procedure, intervention wound pressure time after PCI. Data analysis was performed with SPSS 23.0. $\mathrm{P}<0.05$ were used.

Results. This study includes 191 participants, 122 males $(63.87 \%)$ and 69 females $(36.13 \%)$, who were examined first 48 hours after PCI in the hospital. Patients age $-67.3 \pm 10.49$ years. 150 patients $(78.53 \%)$ were catheterized via radial artery, 41 patients (21.47\%) - via femoral artery. Comparing pain occurrence between PCI through radial artery and through femoral artery there was no statistically significant relation. 102 participants $(53.4 \%)$ felt acute pain at least one time during first 48 hours after procedure. 44 patients (23.04\%) felt pain immediately after PCI: $13.64 \%$ $(n=6)$ of them experienced mP, 43.18\% $(n=19)-$ MP, 29.55\% $(\mathrm{n}=13)$ - SP, 6.82\% $(\mathrm{n}=3)$ - VSP, 6.82\% $(\mathrm{n}=3)$ - WPP. 90 patients $(47.12 \%)$ felt pain after 2 hours following PCI: $13.33 \%(n=12)$ of them experienced $\mathrm{mP}, 37.78 \%(\mathrm{n}=34)$ - MP, $24.44 \%(\mathrm{n}=22)-\mathrm{SP}$, $15.56 \%(n=14)$ - VSP, $8.89 \%(n=8)$ - WSP. 62 patients $(32.46 \%)$ felt pain after 12 hours following PCI: $38.71 \%(n=24)$ of them experienced $\mathrm{mP}, 37.10 \%(\mathrm{n}=23)$ - MP, $14.52 \%(\mathrm{n}=9)-\mathrm{SP}, 3.23 \%$ $(n=2)$ - VSP, 6.45\% $(n=4)$ - WPP. 28 patients $(14.66 \%)$ felt pain after 24 hours following PCI: $39.29 \%(n=11)$ of them experienced $\mathrm{mP}, 28.57 \%(\mathrm{n}=8)$ - MP, $17.86 \%(\mathrm{n}=5)$ - SP, $10.71 \%(\mathrm{n}=3)$ - VSP, $3.57 \%(n=1)$ - WPP. 18 patients $(9.42 \%)$ felt pain after 48 hours following PCI: $33.33 \%(n=6)$ of them experienced $\mathrm{mP}, 33.33 \%$ $(n=6)$ - MP, $11.11 \%(n=2)$ - SP, $16.67 \%(n=3)$ - VSP, 5.56\% $(n=1)$ WPP. In most cases patients characterized the pain as dull (32.23\%), prickling (28.10\%) and tight (31.82\%).

Factors that statistically significantly affect the manifestation of acute postprocedural pain are: arterial hypertension $(\mathrm{p}=0.015)$, female gender $(p=0.014)$, fear before procedure $(p=0.005)$, hema- toma $(\mathrm{p}=0.000248)$, arterial bleeding from puncture site $(\mathrm{p}=0.005)$, intervention site pain during PCI ( $\mathrm{p}=0.000003)$.

117 participants of 191 were included in follow-up group. There were 74 males $(63.25 \%)$ and 43 females $(36.75 \%))$. Patients mean age $-67.3 \pm 10.49$ years. 92 patients $(78.63 \%)$ catheterized through radial artery, 25 patients $(21.37 \%)$ - through femoral artery. There was no statistically significant relation of the results comparing between PCI through radial artery and PCI through femoral artery. 14 patients $(11.97 \%)$ felt prolonged acute pain after 1 week following PCI: $21.43 \%(n=3)$ of them experienced $m P, 28.57 \%(n=4)$ - MP, $28.57 \%(n=4)$ - SP, $14.29 \%(n=2)-V S P$, $7.14 \%(n=1)$ - WSP. 14 patients $(11.97 \%)$ felt pain after 1 month following PCI: $28.57 \%(n=4)$ of them experienced $\mathrm{mP}, 42.86 \%$ $(\mathrm{n}=6)$ - MP, 28.57\% $(\mathrm{n}=4)$ - SP.

Factors that statistically significantly affect the manifestation of acute prolonged pain are: smoking $(\mathrm{p}=0.016)$, puncture location changes during procedure $(p=0.007)$, hematoma $(p=0.0003)$, intervention site pain during PCI $(\mathrm{p}=0.002)$.

For 5 patients $(4.27 \%)$ pain persisted more than 3 months following PCI: $20 \%(n=1)$ of them experienced MP, $80 \%(n=4)$ SP. Patients characterised pain as dull $(60 \%)$ or prickling $(40 \%)$.

Factors affecting the chronic pain manifestation statistically significant are: lower diastolic blood pressure $(\mathrm{p}=0.034)$, puncture location changes during procedure $(\mathrm{p}=0.028)$, hematoma $(\mathrm{p}=0.05)$ and PCI duration $>30$ min. $(\mathrm{p}=0.013)$.

Conclusion. This study revealed that more than half (53.4\%) patients are suffering from acute postprocedural pain. In most cases this pain was referred as dull, prickling and tight felling. Statistically reliable causes for acute postprocedural pain manifestation after PCI during first 48 hours are: arterial hypertension, female gender, fear before procedure, hematoma, arterial bleeding and intervention site pain during PCI. Statistically significant risk factors for acute prolonged pain manifestation after PCI are: smoking, puncture location changes during procedure, hematoma, intervention site pain during PCI.

Chronic pain developed for $4.27 \%$ of the cases. In most cases this pain was referred as dull or prickling. Factors that statistically significant affect chronic pain occurrence are: lower diastolic blood pressure, puncture location changes during procedure, hematoma, PCI duration $>30 \mathrm{~min}$. Still more randomised multicentre study needed.

Correspondence to: agne.klimaite@gmail.com

Gauta 2016-11-21 